\title{
Seroprevalence of Human T-Cell \\ Leukemia/Lymphoma Virus Type I and \\ Type II (HTLV-I/HTLV-II) Infection among Volunteer Blood Donors in Kuwait
}

\author{
Siham Al-Mufti ${ }^{a} \quad$ Alexander Voevodin $^{c}$ Sabeeha Ahmed ${ }^{a}$ \\ Samia Al Hamdan ${ }^{\text {b }}$ Abdul Azis Al-Basheer ${ }^{b}$ \\ aPublic Health Laboratories and ${ }^{\mathrm{b}}$ Blood Bank, Ministry of Health, and \\ 'Department of Microbiology, Faculty of Medicine, Kuwait University, Kuwait
}

\section{Key Words}

Human T-cell leukemia/lymphoma virus type I. Blood donors - Antibodies - Western blot $\cdot$ Kuwait $\cdot$ Iran $\cdot$ India

\begin{abstract}
Objective: The human T-cell leukemia/lymphoma virus type I (HTLV-I) is an etiologic agent of adult T-cell leukemia/lymphoma and tropical spastic paraparesis. One of the major routes of transmission of the virus is through blood transfusion. The aim of this study was to determine the prevalence of HTLV-I infection in volunteer blood donors in Kuwait. Methods: A donation of 97,602 blood units in Kuwait from March 1995 to October 1997 was tested for antibodies against HTLV-I and related virus (HTLV-II). The testing was carried out in three steps: first screening by enzyme immunoassay (EIA) for anti-HTLV-I/ II, second testing of initially positive samples
\end{abstract}

\begin{tabular}{ll}
\hline KARGER & (1) 1999 S. Karger AG, Basel \\
Fax +4161306 1234 $34-7571 / 99 / 0081-0045 \$ 17.50 / 0$ \\
$\begin{array}{l}\text { E-Mail karger@karger.ch } \\
\text { www.karger.com }\end{array}$ & $\begin{array}{l}\text { Accessible online at: } \\
\text { http://BioMedNet.com/karger }\end{array}$
\end{tabular}

by the EIA and final confirmation of true positives by Western blot. Results: Twenty-one HTLV-I-positive donors have been identified (7 Kuwaitis, 5 Indians, 4 Iranians, 2 Bedouins, 1 Omani, 1 Egyptian and 1 Filipino). None of the EIA-reactive samples was positive for HTLV-II by Western blot. The frequency of HTLV-I-positive blood donations was: 1:4,648 and the infection was significantly more prevalent among Indians and Iranians. Conclusion: The prevalence of HTLV-I infection in blood donors in Kuwait is one of the highest in the world and compulsory screening of blood for HTLV-I is fully justified.

\section{Introduction}

The human T-cell leukemia/lymphoma virus type I (HTLV-I) is a retrovirus believed to be the etiologic agent of adult T-cell leukemia/ 
lymphoma (ATLL) and a subset of tropical spastic paraparesis (TSP) [1, 2]. The HTLVI-positive TSP is referred to as HTLV-associated myelopathy (HAM) or HAM/TSP. The role of HTLV-I in the etiology of other human diseases has been suggested, however, in these cases the evidence for an etiologic role of the virus is less strong than that for ATLL and TSP [for a review, see ref. 3]. Most cases of HTLV-I infection are asymptomatic. It is estimated that ATLL or TSP develop in only 2.5$4 \%$ of HTLV-I carriers. The incubation period of HTLV-I-associated diseases is very long, ranging from 10 to 30 years.

The human T-cell leukemia/lymphoma virus type II (HTLV-II) is a virus related to the HTLV-I. The HTLV-II is quite prevalent among drug addicts in Western Europe and the Americas [4-6]. Endemic HTLV-II infection has also been described in different American Indian tribes, as well as in some indigenous populations of Central Africa [711]. No human disease is unequivocally linked to the HTLV-II yet, though the association of HTLV-II with some TSP cases has been reported [12-15].

Both HTLV-I and HTLV-II are transmitted sexually, through breast-feeding, sharing intravenous needles or via blood transfusion. The latter can be effectively prevented by screening blood donors for antibodies against HTLV-I/II. The presence of such antibodies, if properly confirmed, is considered as a very reliable indicator of HTLV-I/II infections. The screening of blood for anti-HTLV-I/II was pioneered in Japan, where it became compulsory in 1986. Since that time the compulsory screening of blood for anti-HTLV-I has been instituted in the US, Canada, France, The Netherlands and Sweden [16]. In 1995 the screening of blood donations was introduced in Kuwait.

In this article we report the results obtained from screening for HTLV-I/II, which indicate that HTLV-I infection is quite prevalent among volunteer blood donors in $\mathrm{Ku}-$ wait, while the HTLV-II infection is absent.

\section{Materials and Methods}

\section{Blood Samples}

Volunteer blood donors donated 97,602 units of blood from March 1995 to October 1997. These units were tested for antibodies against HTLV-I/II. The vast majority of the donors were males $(96.8 \%)$. The percentage of Kuwaitis and expatriates among the donors was 45.75 and $54.25 \%$ respectively.

\section{Screening for Antibodies against}

\section{HTLV-I/HTLV-II Antigens by Enzyme}

Immunoassays (EIA)

Serum samples were tested by HTLV-I 2.0 EIA (Abbott Laboratories, Germany) according to the manufacturer's protocol. Initially reactive samples were tested again in another laboratory using the same method, or in some cases using another EIA test for antibodies against HTLV-I/II antigens (HTLV-I ELISA Cambridge Biotech Corp., Worcester, USA). All repeatedly reactive samples were tested by confirmatory assay.

\section{Confirmatory Testing for Antibodies against} HTLV-I/HTLV-II by Western Blot

HTLV Blot 2.4 test (Diagnostic Biotechnology, Genelabs Diagnostics, Singapore) was used according to the manufacturer's protocol. In the case of HTLV-I the result was considered positive if reactivity with all major antigens of HTLV-I represented on Western blot strips (rgp46-I, p24, gp21, p19 and GD21) was recorded. In the case of HTLV-II, the minimal requirement for positivity was reactivity with HTLV-II-specific antigen (gp46-II).

\section{Results}

The results of the study are presented in table 1. Among 97,602 blood donations tested, 250 EIA-reactive samples were initially identified. Ninety-eight of those samples were repeatedly EIA-reactive and 21 of the latter were proved to be HTLV-I antibody-
46

Med Principles Pract 1999;8:45-50
Al-Mufti/Voevodin/Ahmed/ Al Hamdan/Al-Basheer 
Table 1. The results of screening of blood donations for antibodies against HTLV-I and HTLV-II antigens

\begin{tabular}{llllll}
\hline Total & \multicolumn{2}{l}{ EIA } & & \multicolumn{2}{l}{ Western blot } \\
& + & rep. + & & HTLV-I+ & HTLV-II+ \\
\hline 97,602 & 250 & 98 & & 21 & 0
\end{tabular}

$+=$ Positive; rep. $+=$ repeatedly positive.

Table 2. The age, sex and nationality of HTLV-I-positive blood donors

\begin{tabular}{rrrl}
\hline No. & Sex & Age, years & Nationality \\
\hline 1 & M & $?$ & Omani \\
2 & M & $?$ & Indian \\
3 & M & 26 & Kuwaiti \\
4 & M & 43 & Indian \\
5 & M & 37 & Indian \\
6 & M & 46 & Kuwaiti \\
7 & M & 32 & Kuwaiti \\
8 & M & 22 & Kuwaiti \\
9 & M & 29 & Iranian \\
10 & F & 31 & Bedouin \\
11 & M & 27 & Iranian \\
12 & M & 58 & Indian \\
13 & M & $?$ & Filipino \\
14 & M & 39 & Iranian \\
15 & M & 39 & Egyptian \\
16 & M & 36 & Kuwaiti \\
17 & M & $?$ & Iranian \\
18 & M & 45 & Indian \\
19 & M & 22 & Kuwaiti \\
20 & M & 32 & Kuwaiti \\
21 & M & $?$ & Bedouin \\
\hline
\end{tabular}

$?=$ Data are not available.

positive by Western blot. None of the EIApositive serum samples was HTLV-II-positive when tested by Western blot. The information on sex, age and nationality of HTLVI-positive blood donors is presented in ta-

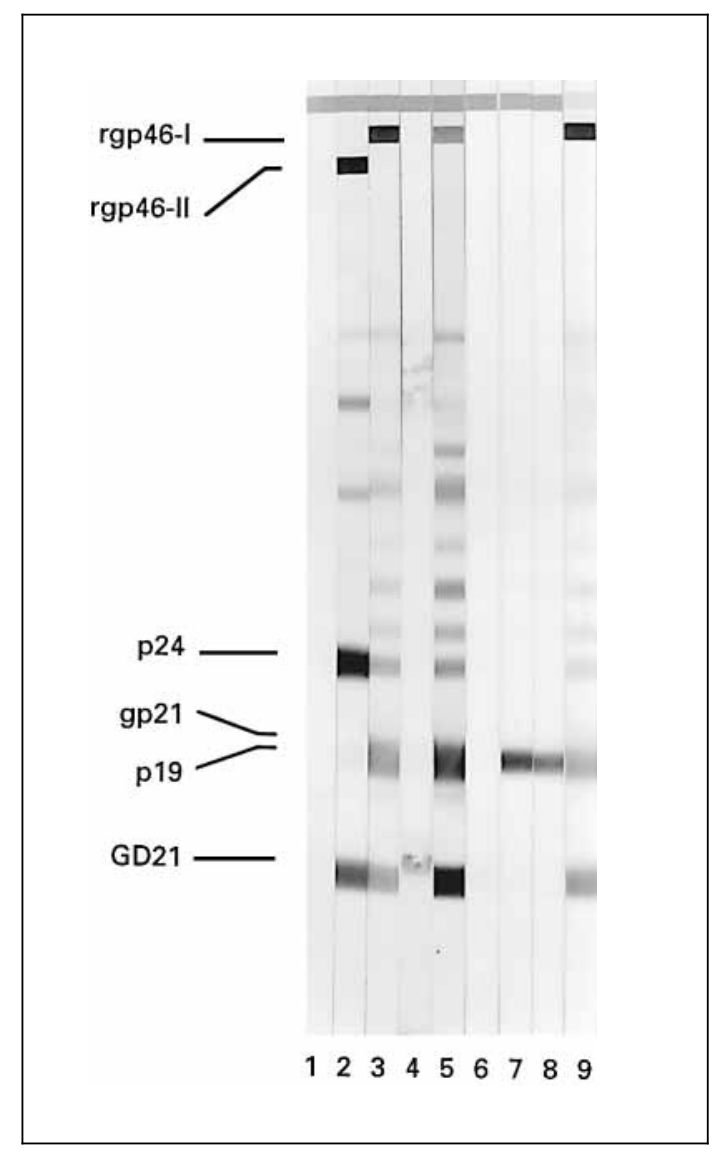

Fig. 1. Representative results of Western blot test. $1=$ Anti-HTLV-I-negative control; 2 = anti-HTLV-II-positive control; $3=$ anti-HTLV-I-positive control; 5-9 = sera from donors; $5,9=$ positive; $4,6=$ negative; $7,8=$ indeterminate. rgp46-I and rgp46-II are HTLV-I- and HTLV-II-specific peptides, respectively; p24, gp21 and p19 are native proteins of HTLV-I; GD21 is a recombinant protein that includes a part of HTLV-I gp21E lacking antigenic determinants in some cases causing false positive reactions [17]. The spots on the strip 4 are artifacts.

ble 2. Typical results of Western blot are presented in figure 1. All positive samples displayed reactivity against all major HTLV-I antigens represented on the Western blot strips (rgp46-I, p24, gp21, p19 and GD21). 
All HTLV-I-positive individuals identified in this study were clinically healthy. The frequency of HTLV-I-positive donations was $1: 4,648$ in the total; $1: 4,724$ in men and $1: 3,123$ in women. The frequencies of HTLVI-positive donations among Kuwaiti nationals and expatriates were 1:6,379 and 1:3,782, respectively. Among the latter, HTLV-I infection was particularly frequent in Indians (5 positives) and Iranians (4 positives). The exact frequency of HTLV-I-positive donations among nationals of countries other than $\mathrm{Ku}-$ wait was not possible to calculate because the data on nationality were not available for all blood donations. However, the distribution according to nationality was known for a sample of blood donations $(n=1,784)$. This allowed to estimate the frequency of HTLVI-positive blood donations from Indians $(1: 318)$ and Iranians $(1: 2,242)$.

\section{Discussion}

It is well known that the prevalence of HTLV-I infection varies significantly among different regions of the world. The 'classical' HTLV-I high prevalence regions are the Southwest of Japan, Caribbean islands and some areas of Central and Western Africa [18-20]. The 'pockets' of HTLV-I infection were also described in some other regions of the world. Until the beginning of the 90s the Middle East has been considered as a region virtually free from HTLV-I infection. Then, the 'pocket' of HTLV-I infection was found in Israel [21]. The HTLV-I infection in Israelis was confined almost exclusively to one relatively closed group: the immigrants from Mashhad, Northeast of Iran, so-called Mashhadi Jews [22]. Later it has been shown that the high prevalence of HTLV-I infection is also characteristic for the Muslim population of Mashhad [23]. The cases of HTLV-I infec- tion and HTLV-I-associated diseases were also described in Iraq [24] and, recently, in Kuwait [25, 26]. After that several more cases of HAM/TSP and 2 cases of ATTL have been diagnosed in Kuwait [27, unpublished]. It is of interest that the molecular analyses of $\mathrm{Ku}-$ waiti HTLV-I have shown close similarity to Iranian and Israeli HTLV-I isolates, strongly suggesting the common origin of all these isolates [25, 28, 29].

These data initiated the screening of donated blood in Kuwait for HTLV-I. Because screening tests for antibodies against HTLV-I antigens allow to detect antibodies against HTLV-II, the latter could also be diagnosed, if present. The first results of such screening showed that HTLV-I infection, indeed is present among blood donors in Kuwait [27]. The need for the HTLV-I screening is unquestionable, for example, in Japan, where the prevalence of HTLV-I infection among potential blood donors is very high. However, the usefulness of the HTLV-I screening in countries with a low prevalence of HTLV-I infection has been debated. The main argument against the introduction of such screening was its low cost-effectiveness. Indeed, it was estimated that, for example, for Britain (where the prevalence of HTLV-I infection in blood donors is about 1 in 20,000) the cost of preventing a single transmission of the virus by blood transfusion is $£ 30,000$ and the cost of preventing each case of HTLV-I-associated disease would be 1.3 million $£$ [30]. The decision regarding the introduction of the screening of blood for HTLV in each country has to be based on compromise. The compromise is to achieve maximum safety of blood within the budget available. One of the prerequisites for making a rational decision is the availability of sufficiently reliable data on the prevalence of HTLV-I infection among blood donors. 
Such information for Arab countries in the Middle East was absent. In this paper we report that the frequency of HTLV-I-positive volunteer blood donations in Kuwait is 1 in 4,650 , which is more than in all countries, except Japan, where the screening of blood for HTLV-I is compulsory. The prevalence of HTLV-I infection in volunteer blood donors in Kuwait is even higher, because some of the donors donated blood several times over the study period. As was expected, we found the prevalence of HTLV-I infection in Iranians is significantly above the average in our sample. Moreover, some of the HTLV-I-positive Kuwaitis and Bedouins identified in this study belong to the families originating from Iran. The DNA sequence characterization of the HTLV-I isolate from one of the Bedouins showed that the virus belongs to the 'Iranian/
Mashhadi' lineage of HTLV-I [Voevodin et al., unpublished]. The unexpected finding was the extremely high prevalence of HTLV-I among Indians. This warrants further investigation.

In conclusion, the prevalence of HTLV-I infection among volunteer blood donors in Kuwait is one of the highest in the world, while HTLV-II infection is absent. Thus the introduction of screening of blood in Kuwait for HTLV-I is fully justified and the screening should be continued.

\section{Acknowledgments}

This work was supported by the Ministry of Health, Kuwait and the Research Grant No. MI 083 from the Kuwait University.

\section{References}

1 Yoshida M, Seiki M, Yamaguchi K, Takasuki K: Monoclonal integration of human T-cell leukemia provirus in all primary tumours of adult $\mathrm{T}$ cell leukemia suggests causative role of human T-cell leukemia virus in the disease. Proc Natl Acad Sci USA 1984;81:2534-2537.

2 Gessain A, Barin F, Vernant JC, Gout O, Maurs L, Calender A, de The G: Antibodies to human T-lymphotropic virus type-I in patients with tropical spastic paraparesis. Lancet 1985;ii:407-410.

3 Uchiyama T: Human T cell leukemia virus type I (HTLV-I) and human diseases. Annu Rev Immunol 1997;15:15-37.

4 Lee HH, Weiss SH, Brown LS, Mildvan D, Shorty V, Saravolatz L, Chu A, Ginzburg HM, Markowitz N, Des Jarlais DC, Blattner W, Allain J-P: Patterns of HIV-1 and HTLV-I/II in intravenous drug abusers from the middle atlantic and central regions of the USA. J Infect Dis 1990;162:347-352.
5 Zella D, Mori L, Sala M, Ferrante P, Casoli C, Magnani G, Achilli G, Cattaneo E, Lori F, Bertazzoni U: HTLV-II infection in Italian drug abusers. Lancet 1990;336:575-576.

6 Fukushima Y, Takahashi H, Hall WW, Nakasone T, Nakata S, Song P, Dinh Duc D, Hien B, Nguyen XQ, Ngoc Trinh T, Nishioka K, Kitamura K, Komura K, Vahlue A, Honda M: Extraordinary high rate of HTLV type II seropositivity in intravenous drug abusers in south Vietnam. AIDS Res Hum Retroviruses 1995;11:637-645.

7 Biglione M, Gessain A, Quiruelas S, Fay O, Taborda MA, Fernandez E, Lupo S, Panzita A, de The G: Endemic HTLV-II infection among Tobas and Matacos Amerindians from north Argentina. J Acquir Immune Defic Syndr 1993;6:631-633.

8 Lairmore MD, Jacobson S, Gracia F, De BK, Castillo L, Larreategui M, Roberts BD, Levine PH, Blattner WA, Kaplan JE: Isolation of human $\mathrm{T}$ cell lymphotropic virus type 2 from Guaymi Indians in Panama. Proc Natl Acad Sci USA 1990;87: 8840-8844.
9 Goubau P, Liu HF, De Lange GG, Vandamme AM, Desmyter J: HTLV-II seroprevalence in pygmies across Africa since 1970. AIDS Res Hum Retroviruses 1993;9:709-713.

10 Gessain A, Mauclere P, Froment A, Biglione M, Le Hesran JY, Tekaia F, Millan J, de The G: Isolation and molecular characterization of a human T-cell lymphotropic virus type II (HTLV-II), subtype B, from a healthy Pygmy living in a remote area of Cameroon: An ancient origin for HTLV-II in Africa. Proc Natl Acad Sci USA 1995;92:4041-4045.

11 Levine PH, Jacobson S, Elliott R, Cavallero A, Cololough G, Dorry C, Stephenson C, Knigge RM, Drummond J, Nishimura M, Taylor M, Wiktor S, Shaw G: HTLV-II infection in Florida Indians. AIDS Res Hum Retroviruses 1993;9:123-127.

12 Hjelle B, Mills R, Swenson S, Mertz G, Key C, Allen S: Incidence of hairy cell leukemia, mycosis fungoides, and chronic lymphocytic leukemia in first known HTLV-II-endemic population. J Infect Dis 1991;163: 435-440. 
13 Harrington WJ Jr, Sheremata W, Hjelle B, Dube DK, Bradshaw $P$, Foung SK, Snodgrass S, Toedter G, Cabral L, Poiesz B: Spastic ataxia associated with human T-cell lymphotropic virus type II infection. Ann Neurol 1993;33:411-414.

14 McFarlin DE: Neurological disorders related to HTLV-I and HTLVII. J Acquir Immune Defic Syndr 1993;6:640-644.

15 Sheremata WA, Harrington WJ Jr, Bradshaw PA, Foung SK, Raffanti SP, Berger JR, Snodgrass S, Resnick L, Poiesz BJ: Association of 'tropical ataxic neuropathy' with HTLV-II. Virus Res 1993;29:71-77.

16 Pagliuca A, Pawson R, Mufti GJ HTLV-I screening in Britain. BMJ 1995;311:1313-1314.

17 Hadlock KG, Goh CJ, Bradshaw PA, Perkins S, Lo J, Kaplan JE, Khabbaz R, Foung SK: Delineation of an immunodominant and human $\mathrm{T}$ cell lymphotropic virus (HTLV)specific epitope within the HTLV-I transmembrane glycoprotein. Blood 1995;86:1392-1399.

18 Hinuma Y, Nagata K, Hanaoka M, Nakai M, Matsumoto T, Kinoshita K, Shirakava S, Miyoshi I: Adult Tcell leukemia: Antigen in ATL cell line and detection of antibodies to the antigen in human sera. Proc Natl Acad Sci USA 1981;78:6476-6480.

19 Blattner W, Kalyanaraman V, Robert-Guroff M, Lister T, Galton D, Sarin P, Crawford D, Catovsky D, Greaves M, Gallo R: The human C retrovirus HTLV in black from the Caribbean region and relationship to adult T-cell leukemia/lymphoma. Int J Cancer 1982;30:257-264.
20 de The G, Giordano C, Gessain A, Howlett W, Sonan T, Alkani F, Rosling $\mathrm{H}$, Carton $\mathrm{H}$, Mouanga $\mathrm{Y}$, Caudie C, Stenger F, Malone G: Human retroviruses HTLV-1, HIV-1, HIV 2 and neurological diseases in some equatorial areas of Africa. J AIDS 1989;2:550-556.

21 Meytes D, Schochat B, Lee H, Nadel G, Sidi Y, Cerney M, Swanson P, Shaklai M, Kilim Y, Elgat M, Chin E, Danon Y, Rosenblat J: Serological and molecular survey for HTLVI infection in a high-risk Middle Eastern group. Lancet 1990;336: 1533-1535.

22 Achiron A, Pinhas-Hamiel O, Doll L, Djaldetti R, Chen A, Ziv I, Avni A, Frankel G, Melamed E, Shohat B: Spastic paraparesis associated with human T-lymphotropic virus type I: A clinical, serological, and genomic study in Iranian-born Mashhadi Jews. Ann Neurol 1993;34:670675.

23 Safai B, Huang JL, Boeri E, Farid R, Raafat J, Schutzer P, Ahkami R, Franchini G: Prevalence of HTLV type I infection in Iran: A serological and genetic study. AIDS Res Hum Retroviruses 1996;12:1185-1190.

24 Denic S, Nolan P, Doherty J, Garson J, Tuke P, Tedder R: HTLV-I infection in Iraq. Lancet 1990;336: 1135-1136.
25 Voevodin A, Al-Mufti S, Farah S, Khan R, Miura T: Molecular characterization of human T-lymphotropic virus, type 1 (HTLV-1) found in Kuwait: Close similarity with HTLV-1 isolates originating from Mashhad, Iran. AIDS Res Hum Retroviruses 1995;11:1255-1259.

26 Farah S, Khan R, Voevodin A, AlMufti S, Rudwan M, Hussein J, Ravindran M: HTLV-1 myelopathy in Kuwait: A report of two patients and review of possible links. Med Principles Pract 1996;5:108-113.

27 Al-Mufti S, Voevodin A, Ahmed S, Al-Hamdan S, Al-Basheer AA: Prevalence of human T-cell lymphotropic virus type I infection among volunteer blood donors in Kuwait. J Acquir Immune Defic Syndr Hum Retrovirol 1997;15:88-90.

28 Voevodin A, Gessain A: Common origin of human T lymphotropic virus type-I from Iran, Kuwait, Israel, and La Réunion Island. J Med Virol 1997:52:77-82.

29 Voevodin A: Substitution $\mathrm{T} \rightarrow \mathrm{C}$ 4783 and $\mathrm{T} \rightarrow \mathrm{C} 6569$ in the pol and env genes of HTLV-I are characteristic for the isolates originating in the Middle East. Leukemia 1997; 11(suppl 3):52-53.

30 Brennan M, Runganga J, Barbara JA, Contreras M, Tedder RS, Garson JA, Tuke PW, Mortimer PP, McAlpine L, Tosswill JH: Prevalence of antibodies to human $\mathrm{T}$ cell leukaemia/lymphoma virus in blood donors in north London. BMJ 1993; 307:1235-1239. 